This sequence is similar to that proposed for the metabolism of itaconate by liver mitochondria ${ }^{3}$ but differs from that suggested for itaconate utilization by another pseudomonad ${ }^{4}$.

Investigations into the nature of enzyme $D$, which is believed to catalyse the direct formation of itaconyl-CoA from itaconate, ATP and CoA, and into the properties of the enzymes here reported, are continuing.

We thank Mr. R. ILEY for technical assistance. This work was supported in part by the Air Force Office of Scientific Research, OAR, through the European Office, Aerospace Research, U.S. Air Force, under Grant AF EOAR 6I-I2.

\author{
Department of Biochemistry, \\ University of Leicester, Leicester \\ (Great Britain) \\ 1 R. A. Cooper and H. L. Kornberg, Biochim. Biophys. Acta, 59 (1962) 480. \\ 2 A. M. Gotto and H. L. Kornberg, Biochem. J., 8I (Ig6I) 273. \\ 3 S. F. Wang, J. Adler and H. A. Lardy, J. Biol. Chem., 236 (I96I) 26. \\ 4 V. Brightman and W. R. Martin, J. Bacteriol., 82 (I96I) 376.
}

R. A. COOPER

H. L. KORNBERG

Received June 22nd, I962

Biochim. Biophys. Acta, 62 (1962) $43^{8-440}$

PN 10003

\title{
Some observations on the lactate dehydrogenase of human neoplasic tissue
}

The electrophoretic heterogeniety of lactate dehydrogenase (L-lactate: NAD oxidoreductase, EC I.I.I.27) has been well documented ${ }^{1-5}$. Although various workers use different methods for isolating the active components, it is generally agreed that five isoenzymes of lactate dehydrogenase can be demonstrated in mammalian tissues. The enzyme electrophoretic pattern obtained from a given tissue appears to be specific for that tissue with respect to the lactate dehydrogenase isoenzymes. The data of PFLEIDERER, AND WACHSMUTH ${ }^{6}$ indicate that human fetal tissues demonstrate considerable similarity in their isoenzymic components. Tissue lactate dehydrogenase undergoes a differentiation process prenatally and during the early post-partum period, finally emerging as the adult-type pattern with multible fractions. This communication compares normal adult tissue lactate dehydrogenase with that obtained from neoplastic tissue and describes an apparent de-differentiation of theenzyme in malignant disease.

Specimens were obtained at autopsy no later than $4 \mathrm{~h}$ post-mortem and rapidly frozen. The tissue was washed once in ice water and then repeatedly in cold saline to remove the majority of contaminating erythrocytes, and subsequently homogenized in ice cold $0.02 M$ veronal buffer ( $\mathrm{pH} 8.6$ ). Supernatant fractions for analysis were obtained after centrifuging at $2000 \times g$ for $0.5 \mathrm{~h}$.

The isoenzymes of lactate dehydrogenase were obtained using a BeckmanSpinco continuous--flow electrophoresis cell, assembled in a cold room, thus maintaining temperatures of less than $10^{\circ}$ across the paper curtain. 32 fractions were obtained for analysis. The reaction mixtures contained $2.5 \mathrm{ml}$ of a fraction, $60 \mathrm{mM}$ sodium L-lactate and $0.94 \mathrm{~m} M \mathrm{NAD}$ in a total volume of $3 \mathrm{ml}$. The reaction was 
followed at $340 \mathrm{~m} \mu$ in a Beckman DU spectrophotometer at I-min intervals for $5 \mathrm{~min}$. Percent enzyme activity in the fractions were determined by planimetric analysis. The results obtained with normal and neoplastic tissue are described in Table I.

In contrast to the diverse isoenzymic pattern of lactate dehydrogenase observed in normal tissue, neoplastic tissue appears to have lost this differentiation to a high

TABLE I

RACTATE DEHYDROGENASE PATTERNS OBSERVED IN NORMAL AND NEOPLASTIC TISSUE

\begin{tabular}{|c|c|c|c|c|c|c|}
\hline \multirow{2}{*}{ Specimen } & \multirow{2}{*}{$\begin{array}{c}\text { Number } \\
\text { of } \\
\text { samples }\end{array}$} & \multicolumn{5}{|c|}{ Percent activity in fractions } \\
\hline & & $V$ & $I V$ & $I I I$ & $I I$ & $I$ \\
\hline Cardiac muscle & 3 & 0.2 & 3.0 & 11.9 & 27.8 & $5^{6.8}$ \\
\hline Skeletal muscle & 2 & 33.2 & 30.0 & $34 \cdot 1$ & 2,0 & 1.0 \\
\hline Liver & 4 & 54.0 & $I_{4} .8$ & 17.2 & 8.0 & $5 \cdot 7$ \\
\hline Lung & 4 & 0.3 & 22.2 & $4^{6.1}$ & 22.9 & 8.6 \\
\hline Kidney & 3 & 0.7 & 12.4 & 30.1 & 27.9 & 28.6 \\
\hline Spleen & 5 & 0.5 & I 8.4 & 50.5 & 20.7 & 9.9 \\
\hline Testes & 2 & 0.2 & $3 \mathrm{I} .2$ & $43 \cdot 7$ & 20.2 & 4.5 \\
\hline Erythrocytes & 8 & & I.9 & 30.9 & 40.4 & 26.6 \\
\hline Leeucocytes & 8 & & I 1.8 & 76.1 & 6. I & \\
\hline Melanoblastoma (lung) & $\mathbf{I}$ & - & - & 100 & - & $-\cdots$ \\
\hline Adenocarcinoma (lung) & 2 & 18.7 & 30.9 & 42.7 & $-\cdots-$ & $\cdots$ \\
\hline Squamous cell carcinoma (lung) & 2 & $\cdots$ & 16.2 & $75 \cdot 4$ & 8.4 & $\cdots-$ \\
\hline Seminoma & 2 & & $\mathrm{I} \cdot 3$ & 72.9 & I9.2 & 0.7 \\
\hline Plasmacytoma & 4 & $\cdots$ & - & 100 & -- & - \\
\hline Liver infiltrate (acute granulocytic leukemia) & I & 1.6 & 21.7 & $44 \cdot 3$ & I8.6 & I 4.0 \\
\hline Liver (metastases from lung, primary) & 2 & I.O & $4 \cdot 5$ & 86.2 & 8.1 & $\cdots$ \\
\hline Erythrocytes (erythroleukemia) & 3 & - & $\mathbf{I} 2.6$ & 82.8 & 4.6 & - \\
\hline Spleen (acute granulocytic leukemia) & 2 & - & 10.3 & 85.2 & $4 \cdot 5$ & $\cdots$ \\
\hline Leucocytes (acute granulocytic leukemia) & 4 & -.-- & $\cdots-$ & 100 & $\cdots$ & \\
\hline Leucocytes (chronic lymphocytic leukemia) & 4 & - & +- & I OO & & \\
\hline
\end{tabular}

degree, the majority of activity now appearing in Fraction III. Those tissue homogenates containing all of the lactate dehydrogenase in Fraction III were concentrated in an effort to detect other areas of activity. These experiments were uniformly negative indicating that the other 4 fractions were probably absent.

TABI,E II

\begin{abstract}
ACTIVITY PERCENTAGE PATTERN AND MICHAELIS CONSTANTS FOR LACTATE ACID OBSERVED IN A MALIGNANT NEOPLASM METASTATIC TO LIVER, ADJACENT AND NON-NEOPLASTIC TISSUE, AND DISTANT NORMAL LIVER
\end{abstract}

\begin{tabular}{|c|c|c|c|c|c|}
\hline \multirow{2}{*}{ Specimen } & \multicolumn{5}{|c|}{ Percent activity } \\
\hline & $V$ & $I V$ & $I I I$ & II & 1 \\
\hline \multirow{3}{*}{$\begin{array}{l}\text { Malignant tissue } \\
\text { Adjacent non-neoplastic tissue } \\
\text { Distant normal liver }\end{array}$} & I.O & $4 \cdot 5$ & 86.2 & S. I & $\cdots$ \\
\hline & I $4 \cdot 3$ & 20.2 & 48.1 & $\mathrm{I}_{4} \cdot \mathrm{I}$ & $3 \cdot 3$ \\
\hline & 56.0 & I 6.1 & 19.2 & $7 \cdot 1$ & $1, f)$ \\
\hline \multicolumn{6}{|c|}{$K_{m}$ for lachate acid acid ( $\left.m M\right)$} \\
\hline Malignant tissue & - & 6.6 & 10 & 3.2 & $\cdot \cdots$ \\
\hline Adjacent non-neoplastic tissue & 7.2 & 7.0 & 8.1 & 3.0 & I. 4 \\
\hline Distant nornal liver & 7.0 & 6.1 & 3.9 & 2.6 & 1.6 \\
\hline
\end{tabular}


Histological sections of the malignancies that displayed multiple lactate dehydrogenase fractions demonstrated surrounding non-neoplastic tissue. The activity patterns in these instances could in no way be correlated with the patterns of normal tissue indicating a loss of specificity possibly due to the adjacent tumor. The data in Table II summarizes results obtained when a nodule, metastatic to liver, an area adjacent to this neoplastic tissue and a section of liver far removed from the tumor were analyzed for lactate dehydrogenase isoenzymes. These results indicate that nonneoplastic tissue immediately surrounding the tumor has lost the pattern specificity of the parent tissue while an area not involved has retained the normal pattern.

The Michaelis constants for lactate acid indicate subtle differences between each of the five isoenzymes in normal tissue (Table III). The tumor enzyme appears

TABLE III

MICHAELIS CONSTANTS FOR LACTATE ACID OBSERVED IN NORMAI, AND NEOPLADTIC TISSUE

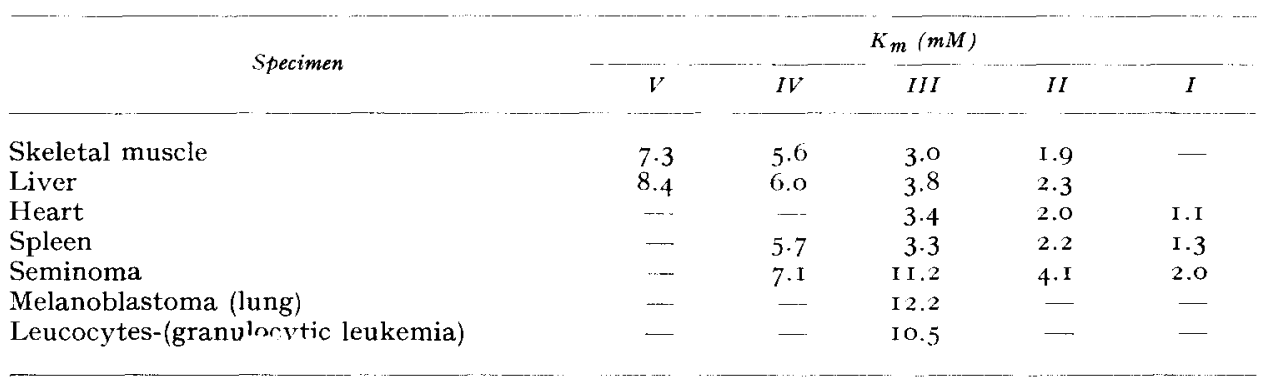

similar to Fraction V in this respect but has the electrophoretic mobility of Fraction III.

In summary, tumor lactate dehydrogenase has lost the high degree of heterogeneity observed in normal human tissue, and the data suggests that Fraction III associated with neoplastic tissue may represent a structurally different protein characteristic of neoplastic tissue. Further investigations are currently being undertaken to elucidate more precisely the nature of tumor lactate dehydrogenase.

This work was aided by grants from the National Institutes of Health (Grant No. C-4843), the Horace H. Rackham School of Graduate Studies of the University of Michigan, and by an Institutional Research Grant to the University of Michigan from the American Cancer Society.

General Medical Research Laboratories,

William H. StaRkWeatheR U.S. Veterans Administration Hospital, HeNRY K. SCHOCH

and the Department of Internal Medicine, University of Michigan, Ann Arbor, Mich. (U.S.A.)

1 E. S. Vesell and A. G. Bearn, J. Clin. Invest., 37 (1958) 672.

2 T. H. Weiland and G. Pfleiderer, Biochem. Z., 329 (I957) II 2.

3 B. R. Hill, Cancer Research., 2 I (196I) $27 \mathrm{I}$.

4 T. H. Weiland, G. Pfleiderer and K. Rajewsky, Z. Naturforsch., 15 (1960) 434.

5 P. G. W. Plagemann, K. F. Gregory and F. Wroblewski, J. Biol. Chem., 235 (1960) 2282.

6 G. Pfleiderer and E. D. Wachsmuth, Biochem. $Z$., 334 (196I) i 85.

Received May 15th-1962. 